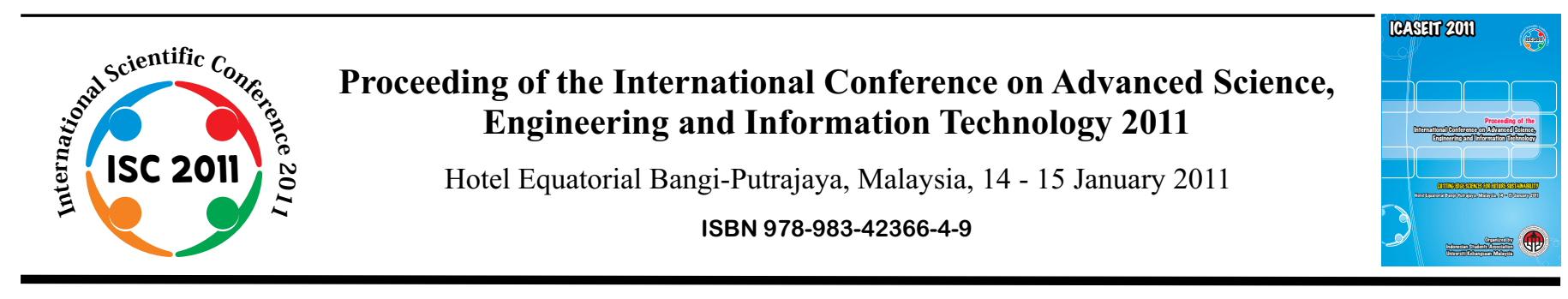

\title{
Effects of Open-Valve and Close-Valve Injections on the Performance of a Port Injection Methane Engine
}

\author{
Taib Iskandar Mohamad ${ }^{1}$, How Heoy Geok ${ }^{2}$, Shahrir Abdullah ${ }^{1}$ \\ ${ }^{1}$ Department of Mechanical and Materials Engineering, \\ Faculty of Engineering and Built Environment, \\ Universiti Kebangsaan Malaysia, 43600 Bangi, Selangor, Malaysia \\ Tel.:+603-89216967,E-mail: taib@eng.ukm.my \\ ${ }^{2}$ Faculty of Engineering and Technology, Multimedia University, \\ Jalan Ayer Keroh Lama, Bukit Beruang, 75450 Melaka, Malaysia. \\ Tel.:+606-252 3307,E-mail: hghow@mmu.edu.my \\ ${ }^{1}$ Department of Mechanical and Materials Engineering, \\ Faculty of Engineering and Built Environment, \\ Universiti Kebangsaan Malaysia, 43600 Bangi, Selangor, Malaysia \\ Tel.:+603-89216013, E-mail: shahrir@eng.ukm.my
}

\begin{abstract}
Increasing concerns over energy security and stricter legislation on automotive exhaust emission limits have triggered greater efforts in utilizing alternatives to petroleum-based fuels. Compressed natural gas (CNG) is one of the promising candidates in terms of emissions and price. In this paper, methane, the major constituent of natural gas (NG), in used to fuel a Ricardo E6 engine and run in a port injection operation with open-valve and close-valve injection. The compression ratio is set at 10.5:1. Methane at 30 bar was supplied to the injector and injection length was adjusted to achieve the desired air fuel ratio (AFR). The minimum advance for best torque (MBT) was determined for 1100rpm speed by measuring the indicated mean effective pressure (IMEP) for combustion at spark advance between $14^{\circ} \mathrm{CA}$ and $35^{\circ} \mathrm{CA}$ BTDC. The result is clearly demonstrated that the performance of the open valve port injection (OVPI) is superior to the one of the close valve port injection (CVPI) with better IMEP, fuel conversion efficiency, indicated power and volumetric efficiency. The observation indicates that OVPI shows steadiness of peak pressures shifts toward top dead centre (TDC) as spark ignitions were advanced compared to CVPI. In terms of combustion characteristics, the OVPI operation yields shorter ignition delay and overall burning duration even at the same phasing angle. Therefore, the open valve operation is preferable for NG port injection due to the fact that injections take place while intake valve is open. It accelerates the charge flow into the cylinder causing higher volumetric efficiency and avoiding the back pressure that happen when high pressure methane is injected while intake valve closes.
\end{abstract}

Keywords - Methane, port injection, ignition timing, open-valve, close-valve.

\section{INTRODUCTION}

Increasing concerns over energy security and the emission of pollutant gases have triggered greater efforts to utilize alternatives fuels for road vehicles. In the presence of these concerns, automotive engine technology is challenged by the increasing divergence between higher power output, better fuel economy and lower pollutant emission requirements [1]. Several alternatives to gasoline and diesel fuels have been studied on current internal combustion engines. Promising results have been obtained from the fuel economy and exhaust emissions points of view [2]-[4]. These include natural gas, which is predominantly methane, 
liquefied petroleum gas (LPG), hydrogen, as well as ethanol and methanol. They are used either as supplement or replacement to gasoline in spark ignition engines. For compression ignition (CI) engines, dual fuel operation with diesel fuel providing pilot ignition source has been successful for heavy-duty applications. CI engines have also benefited from the use of various alternative fuels of vegetable origins as diesel replacement.

Natural gas use has various advantages over conventional fuels mainly due to its potential for higher thermal efficiency (due to higher octane value that allows the use of higher compression ratios), lower $\mathrm{CO}_{2}$ emission (due to lower carbon-to-hydrogen ratio) and less knocking tendency [5][8]. From the supply point of view, natural gas has the advantage of energy diversification and the total reserves have been estimated in the same order as petroleum but with only $60 \%$ of its production rate [9]. LPG is another promising alternative mainly due to its relatively high energy density, high octane rating and low pollutant emissions. It can be stored as liquid at moderate pressure, which gives it major advantage over most other alternative fuels. Methanol on the other hand has a very high octane rating but low heating value and stoichiometric AFR. Thus it leads to higher volumetric fuel consumption when compared to gasoline. Hydrogen fuel for electrically driven fuel cell cars, seen as the future replacement to internal combustion (IC) engine technology, is undergoing extensive research and development and is expected to be in large scale production at some distance of time. IC engine is therefore will remain the key power source in the $21^{\text {st }}$ century until fuel cell vehicles become widespread [10].

The application of indirect fuel injection rather than carburetion has provided improvements in exhaust emissions and vehicle performance. This system introduces fuel at certain higher-than-ambient pressure, which provides more accurate control of fuel quantity injected. In addition, the absence of a venturi as in carburetor reduces intake system pressure reduction. There are mainly two type of indirect injection; single point and multipoint. The single point injection method uses an ECU-controlled fuel injector to introduce fuel into a mixer within the intake system. One common natural gas engine system utilizing this method is referred to GFI, which functions by introducing the expanded fuel to 7 bar into the intake manifold from a single injector nozzle [11]. In the multipoint injection or port injection method, fuel is injected into each intake manifold, where the numbers of fuel injector depends on the number of engine cylinder. This method has several advantages over single point injection including minimizing the risk of intake flashback and improving fuel distribution between cylinders [12]. In this system, NG is injected by individual injector at each cylinder intake manifold near the intake port just before the opening of intake valve. As a result, better control of mixture formation and response to changing speed can be achieved. Thus, it provides the opportunity to reduce the negative effects on the performance compared to carburettor-type or single injector manifold injection [8]. The objective of the paper is to investigate the effects of open-valve and close-valve injection on the performance of a port injection methane engine. The effect of varying the ignition timings were also investigated and analyzed for both open and close-valve injection operations.

\section{METHODOLOGY}

The methane port injection system was tested on a Ricardo E6 engine. Fig. 1 shows the schematic of the experimental set up. The engine is connected and mounted on a common test bed with a direct current electric dynamometer, which functions as motor or brake. Lubricant circulation is driven by an electric motor and water coolant is circulated by separately driven centrifugal pump. The engine has one intake and one exhaust poppet-type valves. A shaft encoder was mounted on the camshaft, giving one TTL signal per camshaft rotation which, corresponds to one signal for every two crankshaft rotations. The signal is set as an input to a pulse generator which output signal at changeable pulse length and delay is generated. This secondary signal which determines injector pulse length is then sent to a MOSFET that functions as a gate for the high power signal from power supply unit $(12 \mathrm{~V}, 5 \mathrm{~A})$ to the fuel injector. Engine speed is controlled from the main unit of the electric dynamometer. Crank position is determined from the photodiode signals flashing through 180-rectangular-slotted disk mounted to the crankshaft.

Cylinder pressures were measured with an un-cooled type Kistler model 6121 A1 pressure sensor attached to the cylinder wall. Pressure signal is amplified through a piezoelectric amplifier. The crank angle and TDC were encoded using the photodiode and slotted disk system. Both crank angle and pressure signals were sent to a data acquisition system at 12000 samples per second rate. Methane is supplied from a 230 bar container and a pressure regulator is adjusted to achieved the desired injection pressures. Injection timings were varied to investigate the effects on engine performance. AFR was set to be stoichiometric and ignition timings were set at MBT. Methane was used as natural gas substitute due to close proximity of properties of these two gases.

There are two throttle valves available on the intake system with one fixed and another adjusted for varying air flow rate. Two injection timings were tested; open valve and closed valve. Methane at 30 bar was supplied to the injector and injection length was adjusted to achieve the desired AFR. The MBT was determined for 1100rpm speed by measuring the IMEP for combustion at spark advance between $14^{\circ} \mathrm{CA}$ and $35^{\circ} \mathrm{CA}$ BTDC. The ignition timing was set using a magnetic strip mechanism attached to the crankshaft and connected to the ignition coil. The schematic of the experimental setup is shown in Fig. 1 and the specifications of the engine are given in Table 1. 


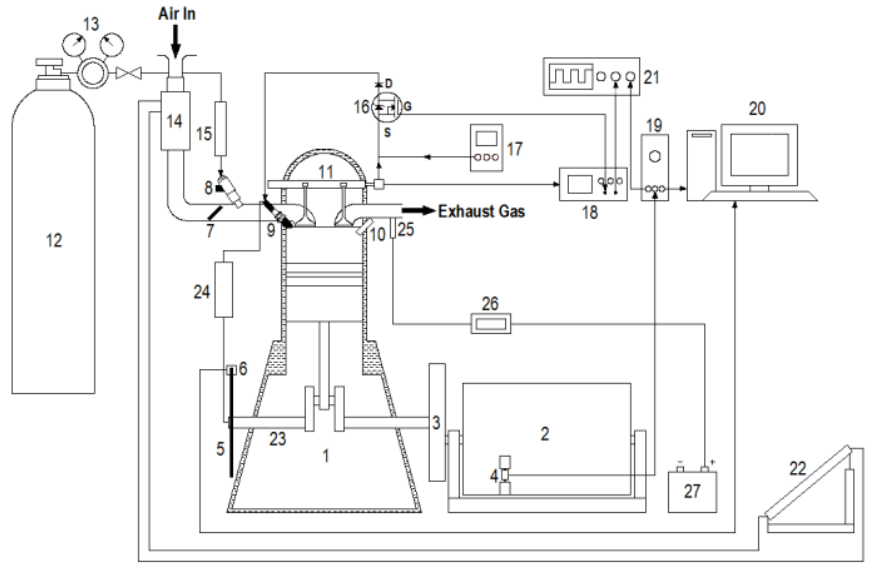

1. Ricardo E6 engine, 2. Electric dynamometer, 3. Flywheel, 4. Load cell, 5. Slotted disk, 6. Photodiode, 7. Throttle valve, 8. Gasoline injector, 9. Spark plug, 10. Pressure sensor, 11. Camshaft and shaft encoder, 12. CNG tank, 13. Pressure regulator, 14. Viscous air flow meter, 15. Fuel flow meter, 16. MOSFET circuit controller, 17. Power supply unit, 18. Pulse generator, 19. Charge amplifier, 20. Data acquisition controller, 21. Oscilloscope, 22. Multislope manometer, 23. Crankshaft, 24. Spark ignition unit, 25. Lambda sensor, 26. Lambda meter, 27. Battery

Fig. 1 Schematic of the experimental setup

TABLE I

SPECIFICATION OF RICARDO E6 ENGINE

\begin{tabular}{|l|c|}
\hline Bore $(\mathrm{mm})$ & 76.2 \\
\hline Stroke $(\mathrm{mm})$ & 111.125 \\
\hline Displacement volume $\left(\mathrm{cm}^{3}\right)$ & 507 \\
\hline Compression ratio & $10.5: 1$ \\
\hline Intake valve open & $8^{\circ} \mathrm{CA}$ BTDC \\
\hline Intake valve close & $33^{\circ} \mathrm{CA} \mathrm{ABDC}$ \\
\hline Exhaust valve open & $42^{\circ} \mathrm{CA} \mathrm{BBDC}$ \\
\hline Exhaust valve close & $8^{\circ} \mathrm{CA}$ ATDC \\
\hline Cooling method & Water cooling \\
\hline Valve clearance (intake/exhaust) & $0.15 \mathrm{~mm} / 0.20 \mathrm{~mm}$ \\
\hline
\end{tabular}

\section{RESULT AND DISCUSSION}

The experimental investigations of methane port fuel injection in two modes; open valve and close valve were carried out. The method that yields the better performance between the two was selected as the basis of comparison with the performance of direct injection. The effects of varying the ignition timings on the overall performance are presented. The performances of comparison are IMEP, fuel conversion efficiency, indicated power and volumetric efficiencies. First, the effects of two fuel injections timings on performance were compared.

Fig. 2 through Fig. 7 show the results from OVPI and CVPI operations at $1100 \mathrm{rpm}$, stoichiometric AFR and 30 bar injection pressure at various ignition timings. In Fig. 2, for OVPI operation, cylinder pressures are plotted against crank angle for one cycle. The effect of spark advance can be seen from the values and timings of peak pressures. In Fig. 3 , cylinder pressures are plotted against cylinder volume.
The area enclosed by the curve is the cyclic integral of pressures against volume which were used to determine indicated work and subsequently the IMEP. Fig. 4 shows the cylinder work over one cycle which represent positive work due to combustion during expansion process and negative work values due to compression process and combustion. Fig. 5 through Fig. 7 shows the same set of results for the CVPI.

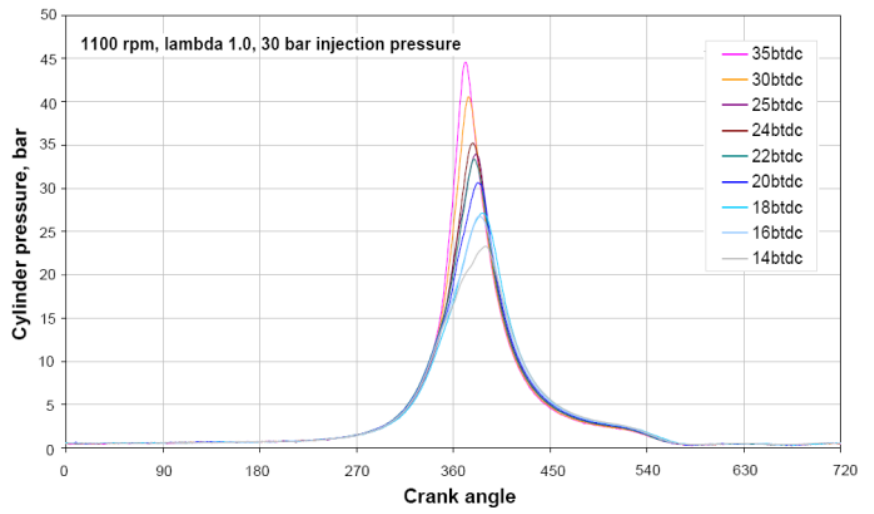

Fig. 2 Cylinder pressures of OVPI at various spark advances

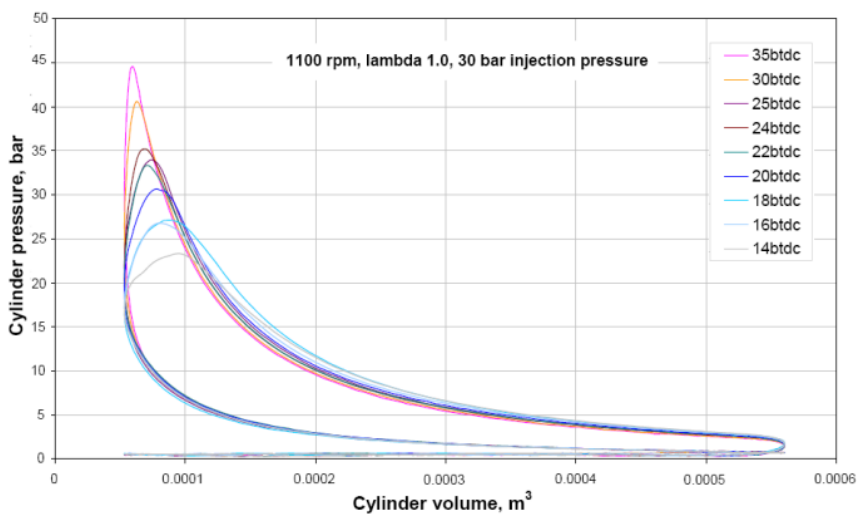

Fig. 3 PV diagram of OVPI at various spark advances

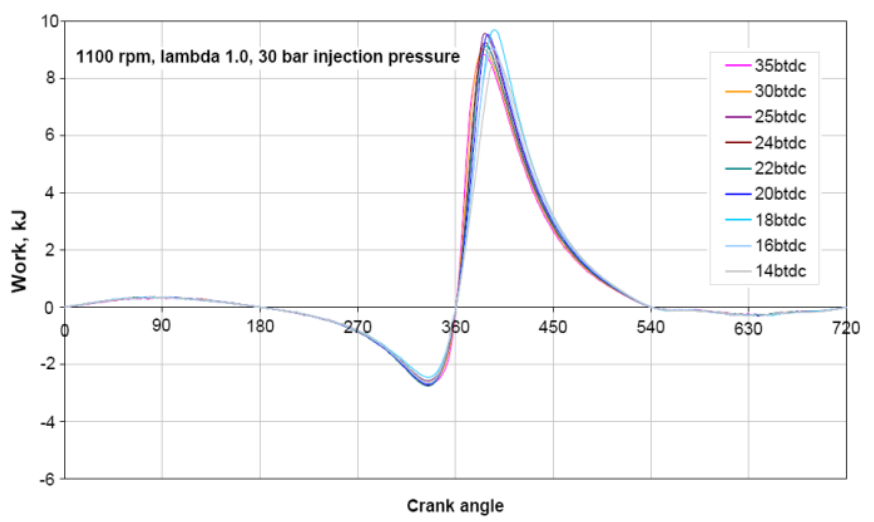

Fig. 4 Cylinder work of OVPI at various spark advances 


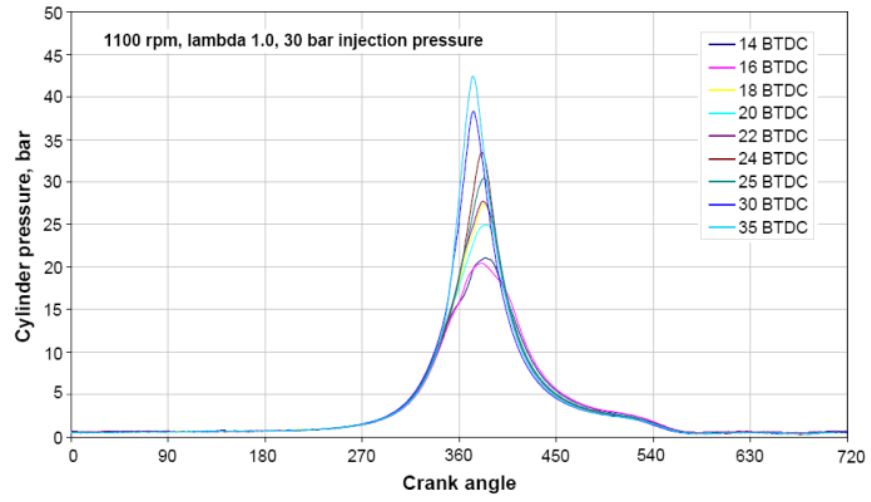

Fig. 5 Cylinder pressures of CVPI at various spark advances

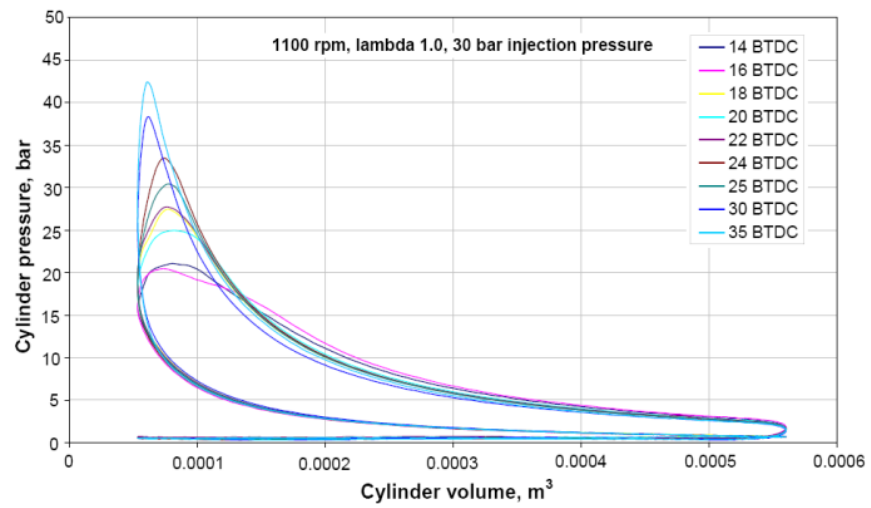

Fig. 6 PV diagram of CVPI at various spark advances

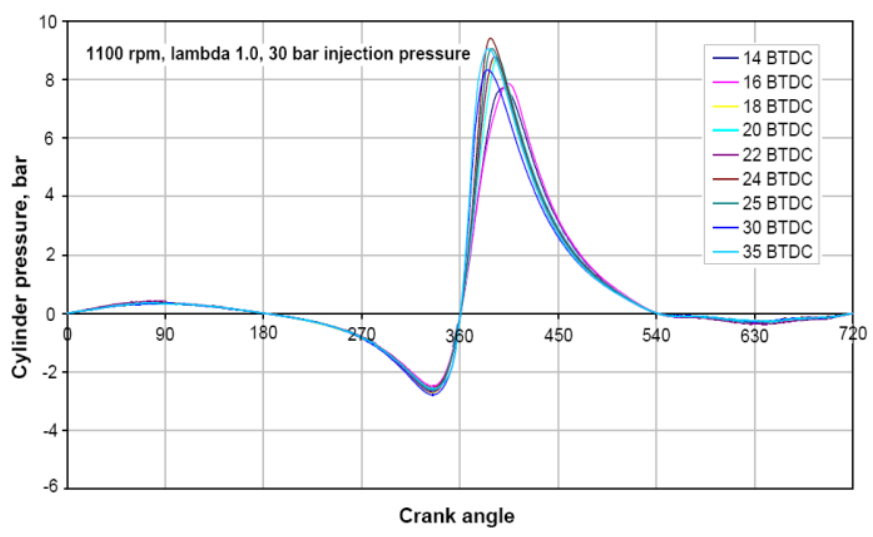

Fig. 7 Cylinder work of CVPI at various spark advances

From Fig. 8 and Fig. 9, it is clearly demonstrated that the performance of OVPI is superior to the one of CVPI with overall higher IMEP and fuel conversion efficiency. In these figures, polynomial fit lines are drawn to show the trend of parameters change with different spark advances. Another observation is that OVPI shows steadiness of peak pressures shifts toward TDC as spark ignitions were advanced compared to CVPI. Volumetric efficiencies of OVPI also showed advantages over CVPI. These advantages were due to the fact that in OVPI operation, better air-fuel pre-mixture in the intake manifold was achieved because methane was injected into the flow of air. In the case of CVPI, methane occupies the inlet area and when the intake valve opens, the incoming flow of air pushes the bulk methane into the cylinder before further mixing inside the combustion chamber can happen.
Fig. 8 and Fig. 9 show that there are similar trends of performance change with varying spark timings where optimal calibration can be achieved. On average, the IMEP of OVPI operation is $7.7 \%$ higher than the one of CVPI. These result in better indicated power of $6.06 \%$ on average as shown in Fig. 10. The volumetric efficiencies of the two methods (Fig. 11) do not show significant difference due to the mass flow rate of air for both OVPI and CVPI operations are almost the same; with the average efficiency of OVPI is only $0.17 \%$ better. The average fuel conversion efficiency of CVPI and OVPI are $23.51 \%$ and $25.25 \%$ respectively. The difference gives OVPI an advantage of $7.42 \%$ more efficient.

The best ignition timings were found to be best at $24^{\circ} \mathrm{CA}$ BTDC for CVPI and at $25^{\circ} \mathrm{CA}$ BTDC for OVPI. At these optimal setting, IMEP and indicated power differ by $1.54 \%$ and $1.71 \%$ respectively. The fuel conversion efficiency of OVPI is $1.55 \%$ better. Volumetric efficiency is the only advantage of CVPI with $75.01 \%$ compared to $74.87 \%$ in the OVPI. However, looking at the results, the OVPI operation produced a more stable performance over the whole range of tested spark timings especially at spark advances more than $25^{\circ} \mathrm{CA}$ BTDC as shown in Fig. 8 and Fig. 9. At these spark advances, the performance drops in CVPI operation become more obvious. The overall performance of OVPI operation are no more than $10 \%$ better but more importantly, they are less effected by the variation of spark timing compared to CVPI operation. Because of these advantages, the OVPI was further investigated with the effects of ignition timing.

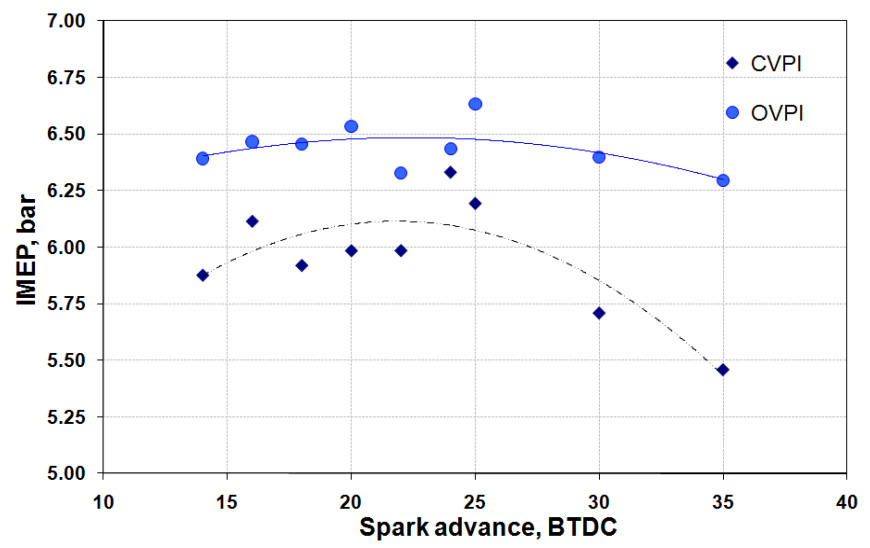

Fig. 8 IMEPs of OVPI and CVPI at various spark advances

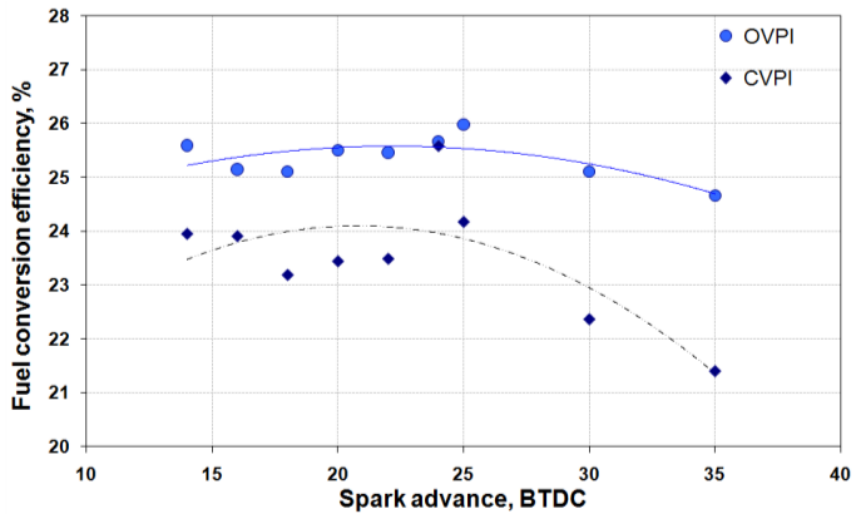

Fig. 9 Fuel conversion efficiencies of OVPI and CVPI at various spark advances 


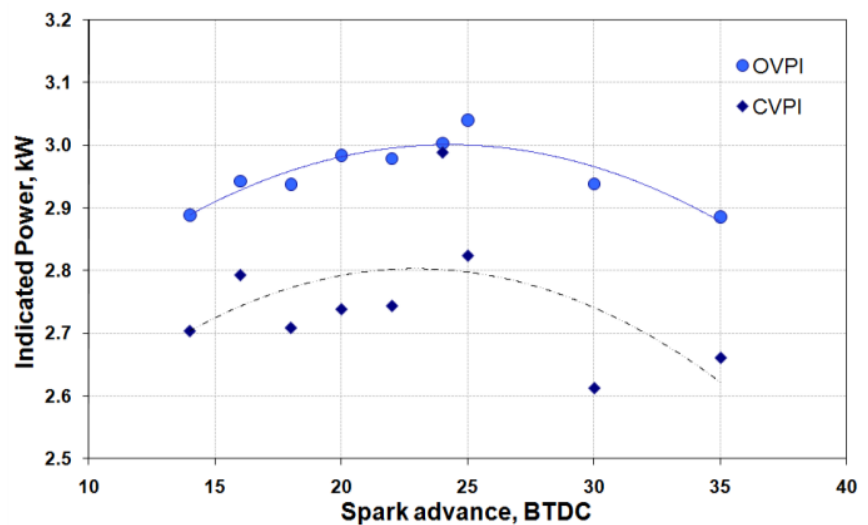

Fig. 10 Indicated power of OVPI and CVPI at various spark advances

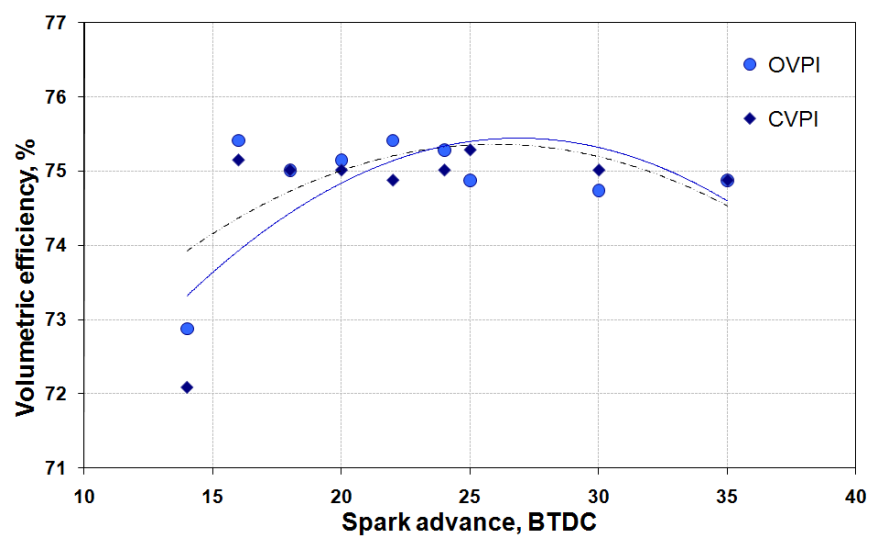

Fig. 11 Volumetric efficiencies of OVPI and CVPI at various spark advances

In addition, the combustion characteristics of both OVPI and CVPI were investigated. The characteristics were described by burning rate $\mathrm{MBF}$ is calculated by normalising the pressure rise due to combustion. It is assumed that the normalised pressure rise is directly proportional to the fraction of mass burnt [13], [14]. The most commonly used definitions for MBF profile is described as the followings [13].

1. Flame development angle, $\Delta \theta_{\mathrm{d}}$. This is the interval between spark event and the time when small but significant amount of fuel is burnt (about 10\%), and referred as ignition delay.

2. Rapid burning angle, $\Delta \theta_{\mathrm{b}}$. The interval when bulk of fuel is burnt and bulk chemical energy released, typically the middle $10-90 \%$ of MBF curve.

3. Overall burning angle, $\Delta \theta_{\mathrm{o}}$. The duration of overall burning process, which is the sum of $\Delta \theta_{\mathrm{d}}$ and $\Delta \theta_{\mathrm{b}}$.

Another useful parameter obtained from $\mathrm{MBF}$ determination is the timing of the angle of maximum heat release, often referred to as combustion phasing angle and usually coincides with the $50 \%$ mass burnt fraction angle. For most SI engines, this occurs between $5^{\circ} \mathrm{CA}$ and $10^{\circ} \mathrm{CA}$ ATDC.

Fig. 12 shows the MBF curve of the OVPI and CVPI at MBT. Injection timing has significant effect on the ignition delay, $\Delta \theta_{\mathrm{d}}$, which can be seen by the $18^{\circ} \mathrm{CA}$ in OVPI and $22^{\circ} \mathrm{CA}$ in CVPI. While the total combustion duration, $\Delta \theta_{0}$, is $24^{\circ} \mathrm{CA}$ for both. The difference of phasing angle, or the angle were peak cylinder pressure (or 50\% of burning) happens between the two methods results in the difference in indicated performance $\left(6^{\circ} \mathrm{CA}\right.$ vs. $\left.10^{\circ} \mathrm{CA}\right)$. Fig. 13 shows $\mathrm{MBF}$ at three ignition times near MBT for the OVPI method. The shifts of combustion processes with respect to crank angle are in order with ignition advance. Combustion duration increases and ignition delay decreases as the ignition is retarded. MBT was achieved at $25^{\circ} \mathrm{CA}$ BTDC where $50 \%$ mass burnt point or the phasing angle is about $6^{\circ}$ ATDC. Table 2 shows the burning parameters for OVPI and CVPI operations.

TABLE 2

BURNING PARAMETERS FOR OVPI AND CVPI

\begin{tabular}{|l|c|c|}
\hline Operations & OVPI & CVPI \\
\hline Ignition delay angle, $\Delta \theta_{\mathrm{d}}$ & $18^{\circ}$ & $22^{\circ}$ \\
\hline Rapid burning angle, $\Delta \theta_{\mathrm{b}}$ & $24^{\circ}$ & $24^{\circ}$ \\
\hline Overall burning angle, $\Delta \theta_{\mathrm{o}}$ & $42^{\circ}$ & $46^{\circ}$ \\
\hline
\end{tabular}

From the combustion analysis, the OVPI operation yields shorter ignition delay and overall burning duration even at the same phasing angle. Therefore, the open valve operation is preferable for methane port injection due to the fact that injection while intake valve is opened. This helps accelerate the charge flow into the cylinder thus increasing volumetric efficiency and avoiding the back pressure that happen when high pressure methane is injected while intake valve closes which can reduces the amount of charge inhaled into the cylinder.

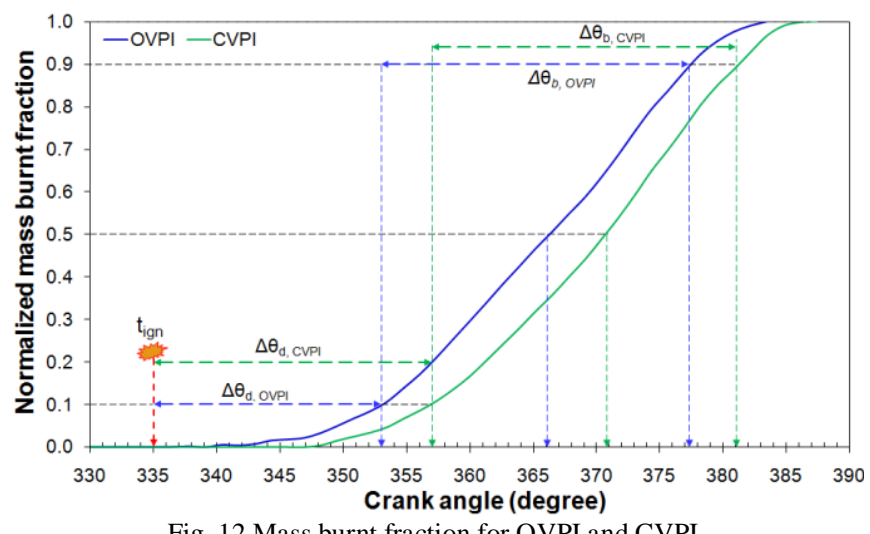

Fig. 12 Mass burnt fraction for OVPI and CVPI

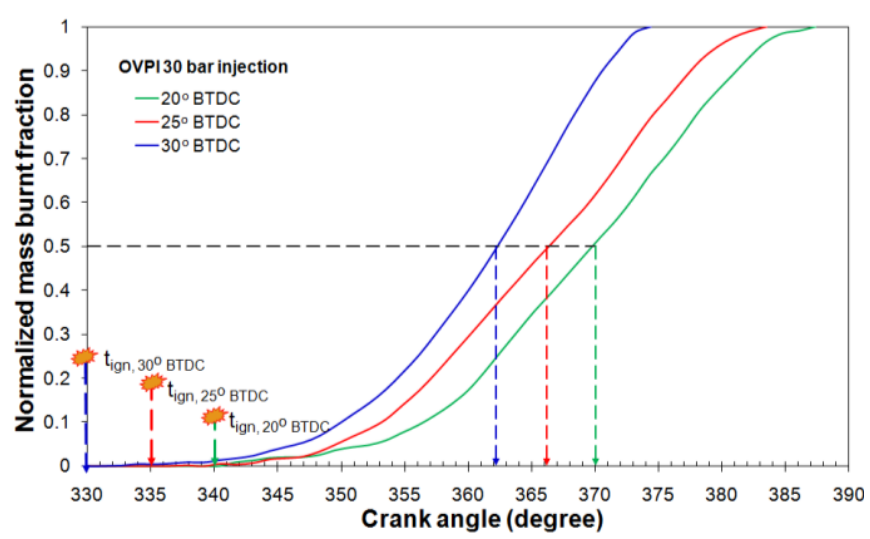

Fig. 13 Mass burnt fraction for OVPI at various ignition timings 


\section{CONCLUSIONS}

As conclusions, it is clearly demonstrated that the performance of OVPI is superior to the one of CVPI with overall higher IMEP, fuel conversion efficiency, power indicated and volumetric efficiency. The observation indicates that OVPI shows steadiness of peak pressures shifts toward TDC as spark ignitions were advanced compared to CVPI. In terms of combustion characteristics, the OVPI operation yields shorter ignition delay and overall burning duration even at the same phasing angle. Therefore, the open valve operation is preferable for $\mathrm{NG}$ port injection due to the fact that injection while intake valve is opened. This helps accelerate the charge flow into the cylinder thus increasing volumetric efficiency and avoiding the back pressure that happen when high pressure methane is injected while intake valve closes which can reduces the amount of charge inhaled into the cylinder.

\section{NOMENCLATURE}

$\begin{array}{ll}\text { ABDC } & \text { After bottom dead centre } \\ \text { AFR } & \text { Air fuel ratio } \\ \text { ATDC } & \text { After top dead centre } \\ \text { BBDC } & \text { Before bottom dead centre } \\ \text { BTDC } & \text { Before top dead centre } \\ \text { CI } & \text { Compressed ignition } \\ \text { CNG } & \text { Compressed natural gas } \\ \text { CVPI } & \text { Close valve port injection } \\ \text { ECU } & \text { Electronic control unit } \\ \text { GFI } & \text { Gaseous Fuel Injection } \\ \text { IMEP } & \text { Indicated mean effective pressure } \\ \text { LPG } & \text { Liquefied petroleum gas } \\ \text { MBT } & \text { Minimum advance for best torque } \\ \text { MOSFET } & \text { Metal-oxide-semiconductor field-effect } \\ \text { NG } & \text { transistor } \\ \text { OVPI } & \text { Natural gas } \\ \text { TDC } & \text { Open valve port injection } \\ \Delta \theta_{\mathrm{b}} & \text { Top dead centre } \\ \Delta \theta_{\mathrm{d}} & \text { Rapid burning angle } \\ \Delta \theta_{\mathrm{o}} & \text { Ignition delay angle } \\ & \text { Overall burning angle }\end{array}$

\section{ACKNOWLEDGMENT}

The authors would like to acknowledge to Ministry of Science, Technology and Innovation (MOSTI) for sponsoring the research funding under project 03-01-02SF0558.

\section{REFERENCES}

[1] C. Stan, Direct Injection Systems: The Next Decade in Engine Technology, Warrendale, PA: SAE International, 2002.

[2] H. Bayraktar, and O. Durgun, "The effects of using gaseous fuels on engine combustion and performance," in The Sixth Combustion Symposium, 1998, p. 273-285.

[3] T. Beer, T. Grant, D. Williams, and H. Watson, "Fuel-cycle greenhouse gas emissions from alternative fuels in Australian heavy vehicles," Atmospheric Environment, vol. 36, pp. 753-763, 2002.

[4] E. Johnson, "LPG: a secure, cleaner transport fuel? a policy recommendation for Europe,” Energy Policy, vol. 31, pp. 1573-1577, 2003.

[5] S. Shiga, S. Ozone, H. T. C. Machacon, T. Karasawa, H. Nakamura, T. Ueda, N. Jingu, Z. Huang, M. Tsue, and M. Kono, "A study of the combustion and emission characteristics of compressed-natural-gas direct-injection stratified combustion using a rapid-compressionmachine," Combustion and Flame, vol. 129, pp. 1-10, 2002.

[6] Z. Huang, S. Shiga, T. Ueda, H. Nakamura, T. Ishima, T. Obokata, M. Tsue, and M. Kono, "Effect of fuel injection timing relative to ignition timing on the natural-gas direct-injection combustion," Journal of Engineering for Gas Turbines and Power, vol. 125, pp. 783-790, 2003.

[7] H. M. Cho, and B.-Q. He, "Spark ignition natural gas engines - a review," Energy Conversion and Management, vol. 48, pp. 608-618, 2007.

[8] H. G. How, T. I. Mohamad, S. Abdullah, Y. Ali, A. Shamsudeen, and E. Adril., "Experimental investigation of performance and emission of a sequential port injection natural gas engine," European Journal of Scientific Research, vol. 30, pp. 204-214, 2009.

[9] A. K. Vourenkoski, "Development of a liquid-phase LPG MPI conversion system," PhD Thesis, Cranfield University, Cranfield, 2004.

[10] K. Morita, "Automotive power source in $21^{\text {st }}$ century," JSAE Review, vol. 24 , pp. 3-7, 2003

[11] S. Carter, J. Heenann, and B. Williamson, "The GFI systemprototype to product," in $3^{\text {rd }}$ International Conference on Natural Gas Vehicles, 1992.

[12] J. C. Guibert, Fuels and Engines: Technology, Energy, Environment, Paris: Institut Francais du Petrole Publication, 1999.

[13] J.B. Heywood, Internal Combustion Engines Fundamentals, McGraw Hill, New York, 1988.

[14] G. M. Rassweiler, and L. Withrow, "Motion Pictures of Engines Flames Corelated with Pressure Cards," SAE Transaction, vol. 42, no. 5, pp. $185-204,1938$ 